\title{
Het Srebrenica-rapport en de geschiedenis van het heden
}

\section{PIETER LAGROU}

\section{Andere tijden, zelfde zeden?}

In juli 1743 legde de Franse hoveling en publicist Saint-Simon de laatste hand aan zijn Mémoires, in werkelijkheid een ooggetuigengeschiedenis van de regeerperiode van Lodewijk XIV. In zijn voorwoord stelde hij de vraag centraal of het geoorloofd is de geschiedenis te schrijven van zijn eigen land en van zijn eigen tijd, een onderneming die erg verschilt van de algemene geschiedenis, die meerdere landen en meerdere eeuwen bestrijkt. Zijn eigen land- en tijdgenoten onder de loep nemen is gevaarlijk, want

wat zou men niet te vrezen hebben vanwege zovele machtigen, gekrenkt in hun eigen persoon of in hun naaste verwanten door de meest onomstootbare en tegelijkertijd meedogenloze waarheden. Een schrijver zou wel zijn zinnen verloren moeten hebben alleen al om het vermoeden te laten rijzen dat hij zich aan het schrijven heeft gezet. ${ }^{1}$

Beter ware het dus een dergelijk werk te laten rijpen achter veilige grendels en er meer dan een generatie overheen laten gaan voor publicatie. Aan dit klassieke retorische voorbehoud voegt Saint-Simon een onverwacht bezwaar toe: de christelijke barmhartigheid.

Kan men de barmhartigheid wel rijmen met het relaas van zoveel passie en ondeugd en de onthulling van zovele misdadige opinies en beschamende motieven van zovele personen voor wie men zoniet alle respect zou hebben behouden en wiens gebreken en wangedrag men bespaard ware gebleven? Is een onschuldige onwetendheid niet te verkiezen boven zo'n onbarmhartige wetenschap? En wat moet men dan niet denken van diegene die zich niet tevreden stelt met datgene wat hij zelf of via anderen vernomen heeft, maar er bovendien van houdt dit alles aan het nageslacht over te leveren ...?

Barmhartigheid en kennis zijn voor Saint-Simon echter niet onverzoenbaar.

Wij moeten begrijpen dat kennis altijd goed is, maar dat het goede of het kwade eruit bestaat welk gebruik wij ervan maken. ... De slechten, die in deze wereld al zoveel voor hebben op de goeden, zouden over nog een bijzonder vreemd voordeel beschikken indien het aan de goeden niet ware toegestaan om hen te onderscheiden, om hen te kennen, en dus om zich voor hen te hoeden ... en hen te laten doorgaan voor wie zij werkelijk zijn en geweest zijn voor het nageslacht, door hen de geschiedenis van hun eigen tijd over te leveren. ... Diegenen die het vertrouwen hebben van de generaals, van de ministers en meer nog, diegenen die het vertrouwen genieten van de prinsen, mogen hen niet in onwetendheid laten over de zeden, het gedrag, de handelingen van de mensen. Zij zijn

1 Saint-Simon, Mémoires, G. Truc, éd. (Édition La Pleiade, 1959 [1743], excerpten, vertalingen PL) 115 . 
verplicht om hen te laten kennen zoals zij zijn, om hen te behoeden voor de valkuilen, de verrassingen en en vooral de verkeerde keuzen. Dit is een barmhartigheid die zich uitstrekt tot diegenen die regeren en die wel in het bijzonder het algemeen belang betreft, dat altijd boven het particulier belang moet verkozen worden. De bestuurders van de publieke zaak, in zijn geheel of ten dele, zijn te druk benomen door hun lopende zaken, te gemakkelijk misleid, gevleid, misbruikt en bedrogen door het grote belang van hun bestuur om duidelijk te kunnen ontwarren en onderscheiden.

Heden, verleden, geschiedenis

De vraag of temporele afstand tussen de observatie en het object al dan niet het wezenskenmerk van de historische discipline uitmaakt, heeft doorheen de tijden complexe en fundamenteel contradictorische antwoorden gekregen. De vaak ten tonele gevoerde stichters van de geschiedschrijving, Thucydides, Tacitus of Macchiavelli, vestigden hun roem met het beschrijven van gebeurtenissen waar zij zelf grotendeels tijdgenoten van waren geweest. Het postulaat van de verstrijkingstermijn, van de verplichte quarantaine-periode vooraleer de historicus aan de slag kon, was hoofdzakelijk een bijproduct van de professionalisering van de geschiedschrijving in de tweede helft van de negentiende eeuw. De historicus dankte zijn statuut van schriftgeleerde niet enkel aan zijn beslagenheid in ontoegankelijke en technisch ingewikkelde disciplines zoals de paleografie, de numismatiek en de oorkondenleer, maar ook, met het verstrijken van de tijd, aan de onpartijdigheid en de intellectuele afstand die hem voor het eerst toestond zich boven het gekrakeel der tijdgenoten te verheffen en met soevereine objectiviteit te kunnen onderscheiden wie es eigentlich gewesen. Het ene ging trouwens niet zonder het andere, daar de professionele historicus zich van het vulgaat der memorialisten onderscheidde door zijn exclusief beroep op archiefbronnen, die pas na een lange verjaringstermijn toegankelijk werden. Zonder archieven geen geschiedenis. De consolidatie van de geschiedwetenschap als academische discipline in verschillende Europese landen rondom de eeuwwisseling, kon nochtans niet voorkomen dat juist hoogleraren geschiedenis zich na 1918 engageerden in een expliciete vorm van diplomatieke dienstverlening en elkaar om de oren sloegen met wit- en zwartboeken over de verantwoordelijkheid voor het uitbreken van het conflict, het historisch statuut van de landsgrenzen of de ultieme waarheid rond oorlogsmisdaden en oorlogspropaganda. Professionele geschiedschrijvers zouden zich bijzonder gedienstig betonen in nazi-Duitsland en het fascistische Italië en in de meeste Europese landen leek het enige recept voor een rehabilitering van de discipline na 1945 dan ook in een steeds verdere vlucht in het verleden te liggen. In Frankrijk werd de tryptiek longue-moyennecourte durée van de Annales-school voor minstens dertig jaar een impliciete waardeschaal voor historisch onderzoek. Ook in Nederland lieten Nicolaas Wilhelmus Posthumus of Jan Romein de eer om een rijksinstituut te leiden dat zich met oorlogsdocumentatie zou bezighouden over aan een patriottisch journalist. Onmiskenbaar voelde het academische establishment en ook de intellectuele avant-garde er weinig voor zijn wetenschappelijke geloofwaardigheid te riskeren door deel te nemen aan de duiding van een conflict dat de Europese samenleving diepgaand had verdeeld en in 
zijn overleven had bedreigd. Oorlogsdocumentatie en academische geschiedschrijving waren misschien niet volstrekt incompatibel, maar zij waren in elk geval functioneel strikt gescheiden.

Slechts in Duitsland was het moeilijker het recente verleden te laten rusten, als de wonden van een externe agressie die tijd nodig hadden om te helen. De Zeitgeschichte als intellectueel complement van de stichting van de Bondsrepubliek had andere ambities dan het te boek stellen van het wedervaren van een land in oorlog. In tegendeel zelfs, lange tijd was die Zeitgeschichte veel meer gericht op de breuk van 1933, de ondergang van de Republiek van Weimar en het succes van de machtsverwerving van de NSDAP dan op de oorlogsjaren zelf, toen Duitsland dood en verderf zaaide in heel Europa. Het concept van de Zeitgeschichte maakte echter wel opgang, ook elders in Europa, vooral vanaf de jaren 1970, als een militante subdiscipline van de geschiedwetenschap, beoefend op de grens van de tijdslijn door geëngageerde historici, overtuigd van de rol die de historiografie kon spelen in het begrijpen van de hedendaagse maatschappij. De inflatie van benamingen die elkaar sinds de Verlichting waren opgevolgd - in het Nederlands waren zowel het adjectief nieuw als zijn superlatief reeds in gebruik — respectievelijk voor de periode vóór 1789 en die vóór 1940 dwong deze pioniers dan ook tot neologismen, zoals 'eigentijdse' geschiedenis of de wel erg paradoxale histoire du temps présent die de Zeitgeschichte in Frankrijk ingang deed vinden. De 'eigen tijd' die het specifieke terrein van deze subdiscipline uitmaakte, werd volgens verschillende criteria afgebakend. Het betrof een verleden dat nog niet helemaal voorbij was, bijvoorbeeld omdat er nog ooggetuigen waren, die zowel als bron konden dienen voor de historicus als als stoorzender, betweter, dwarsligger die de onluisterende aspecten van een kritische geschiedschrijving maar moeilijk konden aanvaarden. In de jaren 1970 en 1980 schoof men vaak een periode van grosso modo 30 tot 50 jaar naar voren, waarbij echter vooral, zoniet exclusief, het oudste uiteinde, de jaren 1930 en 1940 alle aandacht kregen. Ondanks het militante engagement ging het dus om relatief 'oude' geschiedenis, minstens verschillende decennia oud. Meer nog, ging het in dit geval wel degelijk om het 'heden'? Hermann Heimpels definitie van het heden als de periode die begint met de meest recente catastrofe is wellicht de meest simpele formule om het mechanisme van de historische periodisering te begrijpen. $^{2}$ Het heden van 1970 begon dan hooguit in 1945 en de periode die daaraan voorafging was niet 'eigentijds'. De Tweede Wereldoorlog had een nieuwe breuk in de tijdslijn veroorzaakt en afstand geschapen tussen een vóór en een na. Alle 'présentisme' ten spijt waren ook de Zeitgeschichte en de histoire du temps présent al bij al klassieke interpretaties van de grenzen van de geschiedbeoefening. Pas in de late jaren 1980 zou de subdiscipline naar de naoorlogse jaren oprukken en de naoorlogse maatschappij expliciet tot studieobject verheffen. De gebeurtenissen van 1989, 1991 en hun naschokken brachten eens te meer een radicale breuk teweeg. De geschiedenis kende opnieuw een vóór en een na zoals dat sinds 1945 niet meer het geval was geweest. Het 'heden' was meteen fors ingekrompen: waar de hedendaagse

2 Hermann Heimpel, geciteerd in U. Raulff, De l'origine à l'actualité: Marc Bloch, l'histoire et le problème du temps présent (Sigmaringen, 1997) 19. 
periode in de nazomer van 1989 de respectabele leeftijd van 44 jaar had bereikt, ging het voortaan om slechts enkele jaren. De meeste observatoren waren dan ook behoorlijk gedesoriënteerd. Hoe eenvoudig was toch de geopolitiek geweest ten tijde van de Koude Oorlog, toen de bevroren verhoudingen trouwens ook in de rustige klaarheid van de binnenlandse politiek weerspiegeld leken te zijn. Euforie over het 'einde van de geschiedenis' sloeg, mede door de gebeurtenissen in het voormalige Joegoslavië, al even snel om in doemdenken over onafwendbare beschavingsconflicten.

Deze aanloop brengt ons tot het Srebrenica-onderzoek. Nergens in de commentaren op het rapport werd het volstrekt precedentloze karakter van het onderzoek onderlijnd, niet voor de Nederlandse politieke context, maar voor de historische discipline. ${ }^{3} \mathrm{Bij}$ herhaling werd echter de traagheid en de late publicatiedatum aangeklaagd. Vanuit het perspectief van zowat alle precedenten is echter juist de snelheid spectaculair. Het rapport verscheen minder dan zeven jaar na de feiten (het eerste volume van De Jong verscheen bijna 30 jaar na de feiten die het beschreef, het laatste 46 jaar later). Het NIOD had ervaring met onderzoeksrapporten, maar bijvoorbeeld SOTO had zich over echt 'oude' geschiedenis gebogen. Toen het instituut de Srebrenica-taak aanvaardde, waren de gebeurtenissen hooguit een jaar oud. De ontbinding van Joegoslavië was nog volop aan de gang, Nederlandse militairen waren nog ter plaatse aanwezig en bijna alle politieke en militaire verantwoordelijken bekleedden nog steeds dezelfde functie. Terwijl het onderzoek aan de gang was, deden er zich radicaal nieuwe evoluties voor die de gebeurtenissen in een nieuw licht stelden en het denken over militair-humanitaire interventies van nieuwe paradigma's voorzagen, bijvoorbeeld de ontknoping van het conflict in Kosovo en de handelingen van het internationaal gerechtshof in Den Haag. De aanvaarding van de onderzoekstaak door een instituut met een lange traditie van historische respectabiliteit was een transgressie van zowat alle geschreven en ongeschreven regels die de beoefening van de eigentijdse geschiedenis definiëren. De roekeloosheid van de oude dame aan de Herengracht werd dan ook met ongeloof en ontzetting onthaald in het 'milieutje' van collega's en zusterinstituten. Voor wat mezelf betreft, stond het indertijd als een paal boven water dat mijn eigen instituut, het 'Institut d'Histoire du Temps Présent' in Parijs een dergelijk verzoek categorisch had moeten afwijzen. (Voor alle duidelijkheid: er was voor een gelijkaardig onderzoek in Frankrijk zeker aanleiding, maar ongetwijfeld, en het NIODrapport bevestigt dit ten overvloede, zelfs niet een begin van werkelijke wil tot transparantie.) Na een lange worsteling - fysiek, emotioneel en intellectueel - met het rapport kan ik er enkel toe besluiten dat dit een ernstige vergissing ware geweest, gemotiveerd door wantrouwen, wankelmoedigheid en intellectuele luiheid. Het rapport zal geen schoonheidsprijzen behalen en waarschijnlijk ook niet doorgaan voor een model van coherentie. De moed waarmee de onderzoeksploeg zijn onderwerp te lijf ging, kan echter enkel onvoorwaardelijke bewondering oogsten. Het gaat daarbij niet alleen om de lef de toegegooide handschoen te hebben opgeraapt, maar de constante intellectuele ambitie om de tragedie van Srebrenica te trachten te doorgronden in zijn

3 De auteur dankt Dick van Galen Last voor de uiterst instructieve persdossiers die hij regelmatig naar Parijs opstuurde. 
breedste context — Nederlandse politiek, internationale politiek en de lokale Bosnische samenleving.

De politieke weerslag in Nederland was spectaculair en droeg er ongetwijfeld toe bij dat de meest essentiële bijdragen van het rapport in de schaduw bleven van een debat dat zich vooral toespitste op het invullen van Nederlandse namen in een Nederlands falen. De verschillende elementen van het antwoord die in het rapport worden ontwikkeld op de vraag hoe de massamoord in Srebrenica te verklaren valt, vormen een belangrijke contributie tot een beter begrip van het radicaal nieuwe tijdperk dat we sinds een tiental jaren beleven. Historici kunnen zich niet langer tevreden stellen met de geruststellende zekerheden uit een voortaan definitief afgesloten verleden. Modellen over het functioneren van de binnenlandse en internationale politiek gaan niet langer op. De reflectie over deelname aan extreem geweld is niet langer een subspecialiteit in de bestudering van de Tweede Wereldoorlog, met een uitsluitend historisch belang. Het Srebrenica-rapport waagt zich op verschillende vlakken op voor historici volstrekt onontgonnen terrein, met verregaande gevolgen.

\section{Heilzaam positivisme}

Precedentloos in zijn doelstelling valt de lezer nochtans op het eerste gezicht de zakelijke, goed gerodeerde toon van het rapport op. In opbouw en redeneertrant getuigt het van de huisstijl van het NIOD, een stramien dat onmiskenbaar aan Het Koninkrijk der Nederlanden in de Tweede Wereldoorlog doet denken. Het onderwerp wordt zorgvuldig in hoofdstukken en paragrafen ontleed, met talrijke kruisverwijzingen. Elke vraag wordt omstandig ingeleid, met ruime aandacht voor het bronnenmateriaal, omstreden kwesties van cijfers, data, chronologie. Aan theoretische kwesties, aan interpretatie-problemen die de strikte omgang met de bronnen overstijgen of aan het debat met andere auteurs worden geen woorden verspild. De rustige ontleding getuigt van een onwrikbaar vertrouwen dat geverifieerde feiten voor zichzelf spreken. De belangrijkste open vragen betreffen hypothesen over mogelijke alternatieve ontwikkelingen op cruciale kruispunten (what if-vragen: stel dat de pantserwagens met kanonnen in plaats van mitrailleurs waren toegerust; stel dat de Dutchbatters op hun blocking positions op de Servische troepen gevuurd hadden; stel dat het Bosnische leger geen ontsnapping op touw had gezet). Deze worden dan samenvattend geresumeerd in onderdeel-, deel- en hoofdconclusies, die de feitelijke bevindingen opsommen en demonstreren hoe deze volstaan om de meeste what if-vragen op te lossen. De inleiding onderstreept deze zakelijke, common sense benadering. De uiterst complexe vraag naar de verhouding tot de opdrachtgever is een vals probleem, zo lijkt het, eens er goed onderhandeld is over het contract: toegang tot de bronnen, wetenschappelijke onafhankelijkheid. Ook de nadien zo controversiële vraag naar de timing van de publicatie wordt van tafel geveegd met argumenten van intern functioneren operational neccessity zou generaal Kruis het in 1945 genoemd hebben. Die opbouw is duidelijk het resultaat van het redactieproces, waarbij deelauteurs na uitgebreid overleg tot een gezamenlijke tekst en een gezamenlijk interpretatief vergelijk komen, met, zo veronderstelt de lezer, arbitrage aan de top bij meningsverschillen. 
De ijzeren logica van dit stramien is bijzonder efficiënt bij de reconstructie van gebeurtenissen. De beschrijving van de tocht naar Tuzla, bijvoorbeeld, en de analyse van de massamoorden in en rondom de enclave zijn indrukwekkend door de ingehouden toon, de vermenigvuldiging van perspectieven en bronnen, het zuinige doch sprekende gebruik van citaten. Niet alleen is dit onderdeel een model in de beheersing van de emotionele economie in het beschrijven van ondraaglijke gebeurtenissen, het is ook een overtuigende demonstratie dat nauwkeurige reconstructie precieze antwoorden kan leveren op centrale vragen in het onderzoek. Impliciet lijkt het Srebrenicateam te delen in het herwonnen zelfvertrouwen in een gezonde dosis historisch positivisme dat de historiografie van de nazi-genocide kenmerkt. Theoretische debatten over schuldvraag, intentionele of functionele verklaringen, zijn grotendeels steriel voorzover zij niet dadelijk getoetst worden aan de realiteit op het terrein. Door de haarfijne chronologie en analyse van het commandoniveau waarop beslissingen werden genomen, toont de reconstructie aan dat massamoord van mannen niet uitzonderlijk was in deze oorlog, doch dat de systematische moord op een dergelijke schaal niet als dusdanig op voorhand als project bestond. $\mathrm{Zij}$ ontwikkelde zich op het terrein, in een proces van radicalisering, waarbij zowel precedenten als een uitzonderlijk samenspel van lokale omstandigheden een rol speelden. Het is een benadering die veel gemeen heeft met de analyses die de beste hedendaagse historici van de nazigenocide zoals Christian Gerlach en Dieter Pohl een halve eeuw na de feiten ontwikkelden. Een sterker compliment voor het rapport is moeilijk te bedenken.

De onderzoeksmethode die toestaat tot dit resultaat te komen, lijkt ook decennia voorsprong te hebben genomen op de ontwikkeling van de 'Holocaust studies', door de uitzonderlijke combinatie van perpetrator history, hoofdzakelijk gebaseerd op bronnenmateriaal geproduceerd door en voor het internationale tribunaal, en victim history, hoofdzakelijk gebaseerd op (mondelinge) getuigenissen van overlevenden. Er was aanvankelijk veel kritiek op en argwaan tegenover het internationale tribunaal in Den Haag. Internationale justitie leek de schaamlap van een internationale gemeenschap die te kennen gaf niet bereid te zijn het moorden te stoppen zolang het aan de gang was, maar de morele principes van de mensenrechten nadien des te hoger in het vaandel te voeren, door het organiseren van processen en tribunalen. Strategic legalism noemt de Amerikaanse historicus Peter Maguire het geringschattend. ${ }^{4}$ Bovendien werd het tribunaal een gedroomde tribune voor virtuose demagogen als Slobodan Milosevic. Nochtans lijken steeds meer sociale wetenschappers, Balkan-specialisten en humanitaire werkers op het terrein overtuigd van het belang en de positieve effecten van het tribunaal. Troebele polemieken over cijfers, daders of zelfs de realiteit van moordpartijen zijn een belangrijk element in zwarte en witte legenden en zij vormen de brandstof van nationalistische ideologieën. Het is niet illegitiem te stellen dat een gebrek aan kritische historiografie en elementaire factfinding over massamoorden tijdens de burgeroorlog in Joegoslavië in de jaren 1940 mede een rol heeft gespeeld in de verzieking van de relaties tussen bevolkingsgroepen, in het bijzonder vanaf de jaren 1980. Het tribunaal heeft een massa aan onbetwistbaar feitenmateriaal over de

4 P. Maguire, Law and war, an American story (Columbia University Press, 2001 ). 
bevelsstructuur en over aantallen slachtoffers aan het licht gebracht, het heeft schuldigen geïdentificeerd en een klein aantal onder hen ook effectief berecht. De aanwezigheid van een vertegenwoordiger van de Bosnische Serviërs bij de herbegraving van slachtoffers in Potocari op 11 juli dit jaar was waarschijnlijk niet mogelijk geweest indien de internationale gemeenschap niet alles in het werk had gesteld om de realiteit van de moorden op onomstootbare manier te documenteren. Nochtans is voor een tribunaal de reconstructie ondergeschikt aan het vaststellen van de schuldvraag. Bij historisch onderzoek is dit precies omgekeerd en daarin schuilt onmiskenbaar een meerwaarde. De vraag of berechting bijdraagt tot verzoening, geeft aanleiding tot een open debat. Er kan echter geen twijfel over bestaan dat een kritische vaststelling van het feitelijke verloop der gebeurtenissen bijdraagt tot meer serene betrekkingen tussen bevolkingsgroepen.

De manier waarop het rapport het bronnenmateriaal van het tribunaal in real time benut en toegankelijk maakt is ook hier precedentloos. De competentiestrijd tussen rechters en historici die zoveel inkt deed vloeien in het kader van de processen voor misdaden tegen de mensheid tijdens de Tweede Wereldoorlog vanaf de jaren 1960, lijkt hiermee in een volledig nieuw perspectief te staan. Hoewel de historici van de onderzoeksploeg benadrukken dat het voor hen belangrijk was niet verward te worden met de onderzoekers van het tribunaal, lijkt de samenwerking tussen internationale justitie en historisch onderzoeksproject niet fundamenteel conflictueus te zijn geweest. Dat historici gerechtsdossiers benutten, niet decennia na hun totstandkoming, maar meestal nog vóór het proces tegen de beschuldigde in kwestie geopend, laat staan besloten is, is een radicaal nieuw gegeven, met een verregaande impact voor de definitie van de historische discipline. De reflectie hierover is nog niet eens begonnen. De vraag dient trouwens te worden uitgebreid: is het axioma dat de historicus zich enkel over 'oude' feiten buigt en een geheel van gebeurtenissen dat hij als 'afgesloten' beschouwt, het gevolg van praktische beperkingen, of een intellectuele noodzaak? Anders gesteld: indien de omgang met gerechtelijke en overheidsarchieven aan volstrekt nieuwe regels onderworpen wordt, waarbij verjaringstermijnen in bijzondere gevallen en voor een specifieke groep onderzoekers worden opgeheven, vervalt de zelfbeperking die de historische wetenschap zich steeds heeft opgelegd dan zonder meer? Het antwoord op deze vraag is uiteraard onlosmakelijk verbonden met de afbakening van deze 'bijzondere gevallen' en de voorwaarden waaraan een 'specifieke groep onderzoekers' gebonden is, tegenover de bredere groep van vakgenoten en tegenover het publieke debat over het verleden, waarover verder meer.

\section{Nieuwe paradigma's}

Rigoreus positivisme is heilzaam, en wel in de eerste plaats voor de Bosnische samenleving. Als er dus wel één conclusie is die de Nederlandse regering uit het rapport kan trekken, dan is het dat het belangrijk is het werk van de commissie in Bosnië toegankelijk te maken en bij te dragen tot voortgaand onderzoek over de burgeroorlog, wel in het bijzonder in Bosnië, door Bosnische historici. De opgedane 
ervaring moet gedeeld worden door uitwisselingsakkoorden en opleidingsprogramma's. Daar geen enkele samenleving zich een kritische omgang met het eigen verleden eigen kan maken zolang die louter in het buitenland en nog wel in het bijzonder in Den Haag en Amsterdam wordt geschreven, lijkt het logisch Bosnische onderzoeksteams minstens een fractie van de middelen ter beschikking te stellen, met de nodige wetenschappelijke garanties, waarop het internationale tribunaal en het NIOD-team konden rekenen. Het is zonder meer de morele verantwoordelijkheid van het NIOD er over te waken dat dat ook effectief gebeurt.

De gedetailleerde en hoofdzakelijk beschrijvende reconstructie plaatst uiteraard ook de internationale interventie in een schril daglicht. De concrete beschrijving van de dagelijkse vernederingen die de UNPROFOR zich moesten laten welgevallen en het totale verlies van respect dat daar in de ogen van de lokale milities het gevolg van was, is vele malen efficiënter dan welke vorm van rhetorische verontwaardiging dan ook. Op een gelijkaardige manier ontrafelen de mythes van een te duchten militaire tegenstander in een precieze beschrijving van de Servische tactiek, gebaseerd op een combinatie van — kwetsbare - zware artillerie en lokale terreur door paramilitaire benden van beroepsmisdadigers. De ongerijmdheid waarmee militairen een valkuil werden ingestuurd zonder zich van hun eigen bescherming te verzekeren, laat staan die van de bevolking waar zij nominaal garant voor stonden, met volstrekt tegenstrijdige instructies, een ondoorzichtige bevelstructuur (Tuzla, Zagreb, New York of Den Haag), zonder inlichtingen of zelfs luchtfoto's en voor de bevoorrading afhankelijk van de troepen aan wie zij zichzelf als gijzelaars hadden overgeleverd, neemt door de opstapeling van gegevens de proporties aan van een historische aanklacht van collectieve onbekwaamheid, van verblinding en verlamming van zowat alle betrokken nationale en internationale instanties. De grote antwoorden schuilen inderdaad vaak in de kleine details, al dient de lezer daar in dit geval meer dan drieduizend bladzijden lang van overtuigd te blijven.

Nochtans bestaat geen enkele reconstructie uit een simpele opeenstapeling van kritisch getoetste feiten. Zij staat steeds in functie van een betoog en van de vragen die voor het onderzoek het uitgangspunt vormden. Positivisme is heilzaam, maar niet alleenzaligmakend. Waar het onderzoek op epatante wijze het ongelijk bewijst van het vooroordeel dat er voor zo'n recente geschiedenis de nodige bronnen ontbreken, blijft het interpretatieve kader een grotere uitdaging. Zo werd er erg veel onderzoek geïnvesteerd in de analyse van het Nederlandse debat rond de uitsturing van troepen, inclusief een media-analyse en een diepgaande studie van de politieke debatten binnen het parlement en publieke stellingname van politieke protagonisten van regerings- en oppositiepartijen. Niets lijkt normaler: dit is nu eenmaal het analyse-rooster waarmee men de binnenlandse politieke besluitvorming analyseert. Nochtans brengt dit uitvoerige onderzoeksluik bitter weinig op, tenzij een algemene bevestiging van een soort nationale consensus, waarbij alles en allen in grote lijnen in dezelfde richting pleitten. Het rapport is echter wel echt vernieuwend in zijn analyse van het functioneren van de Europese politiek. De perverse effecten van het mechanisme van het roterende voorzitterschap worden breed en diepgaand aangetoond. Het nationale belang het er 
tijdens een voorzitterschap goed van af te brengen brengt een sfeer van union sacrée teweeg, waarbij het normale spel van de democratie tijdelijk wordt uitgeschakeld. Het diplomatieke steekspel waarbij Europese regeringsleiders nationale punten trachten te scoren zonder een globale langere termijnvisie heeft geen gelukkige resultaten opgeleverd in de landbouwpolitiek. Bij de eerste ernstige geweldsuitbarsting in Europa sinds 1945 leidde het tot dramatisch en onvergeeflijk falen. Het rapport overtuigt de lezer ervan dat de traditionele modellen waarmee historici politieke besluitvorming analyseren het niet langer doen. Het beeld van het huidige Europese besluitvormingsproces dat daarbij opdoemt is onrustwekkend door zijn structurele onbekwaamheid en acute democratische deficit. Het pathetische wedervaren van een diplomatiek telegram, bijvoorbeeld, moet zelfs de sterkste Euroscepticus tot een verwoed voorstander bekeren van een coherente en slagvaardige Europese grondwet. En de historici hebben nieuwe paradigma's nodig, daar de nationale lens niet langer het werkelijke proces in zicht krijgt. Het NIOD-rapport biedt geen coherente interpretatiemodellen voor deze nieuwe historische realiteit, maar het heeft alvast de verdienste de diagnose te stellen.

Dit structurele falen van de manier waarop Europa vandaag geregeerd wordt, verergerd door transatlantisch onbegrip en chronische verlamming van de Verenigde Naties is historisch en politiek gesproken de belangrijkste conclusie van het internationale luik van het rapport en als er ergens dringende conclusies te trekken zijn, dan situeren zij zich op dit niveau. De opdrachtgever van het onderzoek was nochtans de Nederlandse regering en de verwachtingen van het publiek spitsten zich toe op specifiek Nederlandse fouten. Het rapport wijst er globaal gesproken op dat een klein land in een erg gebrekkig samenwerkingsverband niet straffeloos aan grote politiek kan doen. De Nederlandse regering beschikte niet over voldoende inlichtingen om zich in dit avontuur te begeven en ook niet over voldoende militaire middelen om de verantwoordelijkheid te dragen waar zij zelf naar solliciteerde. Meer in het algemeen leek het de besluitvormers aan de nodige ervaring te ontbreken om de gevaren realistisch in te schatten. Een zekere zelfvoldane en naïeve traditie van 'gidsland' lijkt daaraan, zoals het rapport suggereert, ook niet vreemd. De Franse rol in de Bosnische tragedie is bijzonder ambigu en de weigering tot transparantie lijkt sommige van de meest ernstige aantijgingen eerder te bevestigen. Het blijft nochtans een open vraag of Franse of ook Britse militairen, met hun ervaring en hun erecode, zich in dezelfde omstandigheden even weinig krijgshaftig zouden hebben opgesteld als hun Nederlandse collega's. De paragrafen die betrekking hebben op de manschappen van Dutchbat zelf behoren tot de meest teleurstellende van het rapport. In de bredere context die ten overvloede geschetst wordt, waren de Nederlandse militairen inderdaad in een hopeloze, pijnlijke en vernederende positie gedropt en het ware al te gemakkelijk hen nadien met schuld en misprijzen te beladen. Het rapport is niet vergoeilijkend, maar het onthoudt er zich systematisch van een aantal conclusies te expliciteren over het morele en intellectuele gehalte van de Nederlandse blauwhelmen. De beschrijving van hun contacten met de beide strijdende partijen, met de lokale bevolking en onderling, en hun houding in crisissituaties, is nochtans weinig verheffend. Een soldaat 
is geen professionele held, maar de afwezigheid van enige opflakkering van verzet en combattieve verontwaardiging laat een erg wrange nasmaak na. De Nederlandse troepen waren in geen geval de incarnatie van de waarden die zo hoog staan in het Nederlandse zelfbeeld en dat heeft niet hen, maar diegenen die in hen hun vertrouwen hadden gesteld, het leven gekost.

\section{Poldermodel?}

De uitdrukkelijk clemente beschrijving van de houding en het gedrag van de manschappen van Dutchbat lijkt menselijk en politiek gesproken zeer begrijpelijk. De afwezigheid van duidelijke temporele en sociale afstand tussen de getuigen en de historici speelde ook eerdere ondernemingen van Zeitgeschichte parten, of het nu om Jean Norton-Cru's eufemiserende beschrijving van de ervaringen van oud-strijders tijdens de Eerste Wereldoorlog gaat, of een bepaalde al te emotionele historiografie gebaseerd op getuigenissen van overlevenden van concentratiekampen. Dat de culturele en emotionele verwantschap met de geïnterviewde Nederlandse soldaten sterker bleek dan met de in Bosnië en elders opgespoorde overlevenden, waarbij de tussenkomst van tolken voor nog extra afstand zorgde, is waarschijnlijk onvermijdelijk, maar bij de redactie van het rapport had men zich misschien beter bewust kunnen zijn van dit affectief onevenwicht. Wat ons terugbrengt bij de eerder gestelde vraag naar de aard van het postulaat van de temporele bufferzone tussen observatie en studieobject: is deze enkel ingegeven door praktische omstandigheden die tot nog toe de bronnen ontoegankelijk maakten, en vervalt zij dus indien die bronnen plots wel toegankelijk worden, of is die afstand ook een intellectuele noodzaak?

Het NIOD-team heeft kunnen rekenen op een uitzonderlijke inspanning tot transparantie vanwege de Nederlandse overheid. Indien Nederland voorbeeld en 'gidsland' is, dan slaat dat veel meer op haar archief- dan op haar militaire politiek. Het fundamentele probleem daarbij is dat die transparantie gold voor de leden van het team, na een persoonlijke veiligheidsscreening, voor documenten die zich op een speciaal beveiligde verdieping van het voormalige bankgebouw op de Herengracht bevonden. Daarmee duit het rapport dus eigenlijk geen tegenspraak, inzoverre andere historici, sociale wetenschappers of elke Nederlandse, Bosnische of Egyptische burger die zich terecht voor de tragedie in Srebrenica interesseert geen toegang krijgen tot hetzelfde bronnenmateriaal. Dit brengt uiteindelijk het wetenschappelijke karakter van de onderneming in gevaar, daar volgens Karl Popper een analyse slechts wetenschappelijk is wanneer zij getoetst, weersproken en potentieel vals bevonden kan worden. Een recensie-oefening als deze, waarbij het rapport bloemen en bloempotten krijgt toegegooid door een volstrekte leek, die geen enkele van de gebruikte bronnen zelf ter hand nam, is wel een erg gebrekkige vorm van peer review. Uiteraard was dit exclusieve inzagerecht een conditio sine qua non voor het onderzoek. De openheid die hierbij aan de dag werd gelegd was al uitzonderlijk genoeg en men kan van geen enkele instelling verwachten dat zij haar meest recente archieven met betrekking tot een traumatisch falen zonder meer publiek uitpakt. Voor het NIOD-team bleef er dus 
enkel de keuze over deze condities te aanvaarden of helemaal geen onderzoek te doen en Srebrenica nog voor enkele decennia in de archiefdozen te laten bezinken? Ik ben persoonlijk de opinie toegedaan dat wat ik hogerop de 'NIOD-huisstijl' noemde, de nadelen en de gevaren van deze onvermijdelijke toestand eerder verergerd heeft. Sinds Loe de Jong zich aan het schrijven van zijn Koninkrijk der Nederlanden in de Tweede Wereldoorlog zette, heeft teamwerk in het NIOD een zekere vorm van democratisch centralisme ingehouden, krachtig én eensgezind, één voor allen, allen voor één. Waarom moet een onderzoeksrapport eenduidige conclusies en interpretaties aanbieden, die als Russische popjes in elkaar passen, van de kleinste paragraaf tot de ultieme epiloog? Waarom die onweerstaanbare drang tot consensus, en als er nog een meningsverschil overblijft, dan vergaderen we dat wel plat? Of gaat het om een meer verbreid euvel dat de Nederlandse maatschappij kenmerkt, een onbehagen over onenigheid, een chronische onbekwaamheid om om te gaan met dissidentie? Het is een traditie die er bijvoorbeeld toe bijdraagt dat ik nergens elders dan in Nederland de bevreemdende praktijk tegenkwam waarbij een recensie als deze systematisch nog voor haar publicatie aan de gerecenseerde auteurs wordt voorgelegd. In de pers werd uitvoerig gealludeerd op conflicten en verschillende interpretaties in de onderzoeksgroep. Dat lijkt a priori bijzonder normaal en zelfs geruststellend, daar het suggereert dat het team bestond uit onderzoekers die in staat zijn autonoom na te denken en dat het teamverband niet al te autoritair was om dergelijke verschillende benaderingen toe te laten. Waarom kon deze natuurlijke stand van zaken in een pluralistische democratie en een kritische wetenschapsbeoefening op geen enkele manier in het rapport tot uitdrukking komen? Zelfs de Supreme Court, de ultieme grondwettelijke autoriteit in de Verenigde Staten, assorteert de publicatie van zijn uitspraken met een minority opinion. Aangezien het rapport sowieso nadien het voorwerp werd van een parlementair onderzoek, zouden het Nederlandse parlement en de Nederlandse publieke opinie niet beter gediend geweest zijn door een tegensprakig rapport, waarbij verschillende auteurs verschillende analyses uiteenzetten en de lezer voor volwassen genoeg aanzien daaruit haar of zijn eigen opinies te puren? Vooral, zou het fundamentele probleem van een gebrek aan adequate externe toetsing en tegenspraak niet beperkter geweest zijn indien men had toegestaan dat de interne discussie ook in het rapport tot uitdrukking kwam? Deze onweerstaanbare drang tot consensus krijgt in het licht van de conclusies van het rapport zelf een ironische nasmaak. Wordt daarin niet precies de vinger gelegd op de al te consensuele manier waarop alle segmenten van de Nederlandse politiek op eerder onnadenkende wijze voor een uitzending pleitten, zonder het nodige debat, zonder de nodige tegenspraak? Is de remedie voor een al te collectief falen een al te collectief culpa nostra, een homogeen verdict van de onderzoeksploeg waaruit de eerste minister zonder verder tegensputteren zijn conclusies trekt? Diende het rapport het debat te onderbouwen met kritische informatie, of diende het dat debat simpelweg af te sluiten? 


\section{Barmhartigheid}

Het Srebrenica-rapport kreeg heel wat kritiek, op de stijl, de omvang, de coherentie en de leesbaarheid. Die kritiek is deels terecht. Te weinig commentatoren hebben nochtans mijns inziens erkend dat het een mijlpaal is in de geschiedschrijving van het recente verleden, chronologisch en methodologisch grensverleggend, baanbrekend waar het aantoont dat traditionele interpretatiemodellen niet langer volstaan om de nieuwe historische realiteit die we sinds een tiental jaren beleven, te verstaan. De impact van het rapport zal zeker langer nazinderen in de reflectie over de beoefening van de hedendaagse geschiedenis, haar grenzen en haar mogelijkheden, dan in het Nederlandse politieke debat. Collega's historici moeten ootmoedig hun bewondering uitdrukken voor de verpletterende uitdaging die de onderzoekers aanvaardden en consequent te lijf gingen, ondanks de materiële, politieke en vooral conceptuele drempels, in een intellectueel avontuur dat hen erg ver leidde van de vertrouwde horizonten van het historisch onderzoek. Barmhartigheid is in de context van Srebrenica een anachronistisch woord. Nochtans lijkt het engagement van de onderzoekers op datgene waar Saint Simon een kwart millennium eerder voor pleitte. De historicus heeft een verantwoordelijkheid om beleidsvoerders en de publieke zaak door kritische analyse voor 'valkuilen, verrassingen en verkeerde keuzen' te behoeden. Het NIOD-rapport is geen definitief besluit, maar het is een les in intellectuele moed en het opent een debat waarvan het belang voor. historici en voor de richting die onze beleidsvorming vandaag de dag uit moet, niet overschat kan worden. 


\title{
Oordelen in uitersten
}

\author{
J. C. H. BLOM \\ B. G. J. DE GRAAFF \\ D. C. L. SCHOONOORD
}

De verschillen in waardering, toonzetting en invalshoek tussen de recensieartikelen van J. W. L. Brouwer, J. W. Honig en P. Lagrou zijn opmerkelijk groot. Waar Brouwer 'de onvolkomenheden in de redactie het meest in het oog' vielen, ziet Lagrou in het Srebrenica-rapport 'een mijlpaal' in de geschiedschrijving van het recente verleden. Waar Honig opent met 'De hoofdbezwaren tegen het NIOD-rapport luiden kort en bondig : het werk is te lang en het kwam te laat', concludeert Lagrou tot 'chronologisch en methodologisch grensverleggend, baanbrekend waar het aantoont dat traditionele interpretatiemodellen niet langer volstaan.' Waar Brouwer 'het gebrek aan samenhang' accentueert en Honig meent 'dat niet goed genoeg nagedacht werd over de functie van het rapport', besluit Lagrou tot 'een les in intellectuele moed' en opening van 'een debat waarvan het belang voor historici en voor de richting die onze beleidsvorming vandaag de dag uit moet, niet kan overschat worden.'

Het was verleidelijk om de reactie op de drie beschouwingen over het Srebrenicarapport te beperken tot bovenstaande constatering: tegenover de wat benepen redactionele missers zoekende Brouwer en de wat zure Honig verschijnt dan de brede visie van Lagrou, die aard en betekenis van het onderzoek wel onderkende en ruimhartig formuleert. Dat Brouwer en Honig gezien de eigen omschrijving van hun hoofdproblemen kennelijk alleen op ondergeschikte punten inhoudelijke bezwaren hebben en zulke bezwaren bij Lagrou uitdrukkelijk in het niet vallen bij de positieve waardering zou voor zo'n korte reactie een extra argument kunnen zijn.

Maar een dergelijke afdoening zou de inhoudelijk belangwekkende beschouwingen, die de artikelen van Brouwer en vooral Honig 1 wel degelijk ook bevatten geen recht doen. Het zou ook de mogelijkheid wegnemen om bij Lagrou's betoog enkele kanttekeningen te maken. Het zou voorts verhinderen enerzijds op sommige punten expliciet toe te geven dat er inderdaad ook dingen zijn misgegaan en anderzijds enkele zaken recht te zetten.

\section{Vorm, omvang, timing en hoofdonderwerp}

Laten wij beginnen met toegevingen. Inderdaad, Brouwers priemende vinger wijst het haarscherp aan: slivovitsj wordt niet gebrouwen maar gestookt! En bladzijde 1021 bevat een pleonasme. Dit had zo nooit in het rapport mogen staan. Er zijn meer (en

1 Terzijde zij opgemerkt dat bij Honig kennelijk sprake is van voortschrijdend inzicht. In de Militaire Spectator, CLXXI (2002) x, 514-516 stond een recensie van het rapport, die zeker ook kritisch was maar in een veel gematigder toonzetting dan zijn bijdrage voor dit tijdschrift. 